\title{
THE NUTRITIONAL STATE OF CHILDREN WITH CHRONIC RHEUMATIC HEART DISEASE
}

\author{
BY \\ JOSEPH BENN, M.D., M.R.C.P. \\ Tutor in Medicine, University of Bristol
}

Gray Hill (1933) stated that while the child's physical development may be arrested by severe rheumatic heart disease, most patients admitted to hospital in the active state of rheumatism or chorea are little below normal height and weight, and not uncommonly they are tall and well grown. With rest in bed the weight approached normal within a few months. The long-term effect on nutrition is by no means so clear. The problem is made more difficult because it is generally agreed that rheumatic heart disease is more common in children from poor homes (Swift, quoted from Nelson's "Loose Leaf Medicine"; Ministry of Health Report, 1927; Miller, 1928; Campbell and Warner, 1930; Glover, 1934; Medical Research Council Report, No. 114, 1927).

Vining (1928) found that 75 per cent. of his rheumatic cases were under weight as compared with fifty-nine of one hundred elementary school children with a history of good health.

\section{Method of Investigation}

In the present investigation records of rheumatic children were available from 1927 . Their numbers were few before 1932 , so that only cases seen since that time have been considered. The children investigated have all attended a school cardiac clinic, where they are weighed regularly. The scales used have been tested and found accurate. The weight of each child on its last appearance at the cardiac clinic was considered to be the best criterion, because the longer the period since infection the greater the expectation of any inhibiting effect of a heart lesion on the child's growth. The ages of children when last weighed ranged between 8 and 17 years, but since the majority were between the ages of 10 and 15 years inclusive, patients outside this range were excluded. Any child with a history of serious illness other than rheumatism was not included. Thus no case having had nephritis, pulmonary tuberculosis, any long illness, or a history of erythema nodosum has been included. It is realized that a few rheumatic cases with erythema nodosum due to streptococcal sensitivity must in this way have been excluded, but it was considered a necessary precaution because of the possibility of a tuberculous etiology.
The rheumatic cases have been divided into two groups, those left with persistent signs of heart disease, and recovered cases, that is, children who have had rheumatic infection but when last seen had no evidence of heart disease. The criteria of rheumatic heart disease were the presence of one of the following: an aortic diastolic murmur, a mitral diastolic murmur, a mitral systolic murmur of organic type with or without cardiac enlargement. Mitral systolic murmurs were considered organic if loudest in the mitral area, if the murmur was louder when the child was rolled to the left and fainter when sitting upright. Any patient with a soft generalized precordial murmur was excluded even with a history of acute rheumatism, although a certain number will eventually prove to be organic. Cases of rheumatic heart disease in which the pathognomonic murmur later disappeared have not been included.

Two types of control have been used. The first consists of the recovered cases already referred to, and they were considered particularly suitable as they came from the same social class and type of home as those with organic disease, and therefore the factors of poverty and under-nutrition presumably have the same importance. The second group of controls consists of a random sample of Bristol school-children seen in 1947, there being fifty children of each sex for each year of age. They will be referred to in future as normal controls.

It is generally agreed that in the past twenty years both the height and weight of British schoolchildren have increased greatlv, so that a comparison of figures obtained in 1932 and 1947 would be invalid. The children with heart disease and the recovered cases were therefore divided into three groups (table 1). Children last weighed between 1932 and 1937 have been labelled Group A, those last weighed between 1937 and 1942 Group B, and those between 1942 and 1947 Group C. The mean weight and number of children of each year of age have been tabled, the sexes being considered separately.

Recent rheumatic infection causes a temporary loss of weight; relapses are frequent but are much more common during the first three or four years after the first attack. Thus Wilson and others (1928) found 80 per cent. of relapses occurred within three years of the first infection. Mackie (1926) found 
TABLE 1

THE WEIGHT IN KILOGRAMMES OF CHILDREN WITH RHEUMATIC HEART DISEASE, OF RECOVERED CASES, AND OF NORMAL CONTROLS

\begin{tabular}{|c|c|c|c|c|c|c|c|c|c|c|c|c|c|c|c|}
\hline \multirow{3}{*}{ Series } & \multirow{3}{*}{ Group } & \multirow{3}{*}{ Sex } & \multirow{3}{*}{ Type of case } & \multicolumn{10}{|c|}{ Age in years } & \multirow{2}{*}{\multicolumn{2}{|c|}{15}} \\
\hline & & & & \multicolumn{2}{|r|}{10} & \multicolumn{2}{|r|}{11} & \multicolumn{2}{|c|}{12} & \multicolumn{2}{|c|}{13} & \multicolumn{2}{|r|}{14} & & \\
\hline & & & & No. & $\begin{array}{c}\text { Mean } \\
\text { wt. in } \\
\text { kg. }\end{array}$ & No. & $\begin{array}{c}\text { Mean } \\
\text { wt. in } \\
\text { kg. }\end{array}$ & No. & $\begin{array}{c}\text { Mean } \\
\text { wt. in } \\
\text { kg. }\end{array}$ & No. & $\begin{array}{c}\text { Mean } \\
\text { wt. in } \\
\text { kg. }\end{array}$ & No. & $\begin{array}{c}\text { Mean } \\
\text { wt. in } \\
\text { kg. }\end{array}$ & No. & $\begin{array}{c}\text { Mean } \\
\text { wt. in } \\
\text { kg. }\end{array}$ \\
\hline \multirow[t]{14}{*}{$\mathbf{I}^{*}$} & \multirow[t]{4}{*}{ A } & \multirow[t]{2}{*}{$\mathbf{M}$} & R.H.D. & 1 & $35 \cdot 0$ & 2 & $33 \cdot 2$ & 1 & $40 \cdot 9$ & 16 & $38 \cdot 4$ & 9 & $44 \cdot 2$ & 3 & $45 \cdot 9$ \\
\hline & & & Recovered & Nil & - & Nil & - & 1 & $50 \cdot 9$ & 6 & $42 \cdot 6$ & 1 & $35 \cdot 5$ & 2 & $42 \cdot 7$ \\
\hline & & \multirow[t]{2}{*}{$\mathbf{F}$} & R.H.D. & 1 & $30 \cdot 0$ & 2 & $36 \cdot 1$ & 3 & $37 \cdot 7$ & 18 & $43 \cdot 6$ & 12 & $42 \cdot 1$ & 1 & $39 \cdot 3$ \\
\hline & & & Recovered & Nil & - & 1 & $37 \cdot 7$ & 1 & $28 \cdot 2$ & 8 & $43 \cdot 1$ & 7 & $44 \cdot 2$ & 1 & $58 \cdot 2$ \\
\hline & \multirow[t]{4}{*}{ B } & \multirow[t]{2}{*}{$\mathbf{M}$} & R.H.D. & Nil & - & 2 & $39 \cdot 8$ & 1 & $45 \cdot 5$ & 8 & $39 \cdot 4$ & 12 & $49 \cdot 0$ & 2 & $46 \cdot 7$ \\
\hline & & & Recovered & Nil & - & 1 & $33 \cdot 6$ & 2 & 33.9 & 7 & $39 \cdot 3$ & 5 & $53 \cdot 5$ & 1 & $54 \cdot 1$ \\
\hline & & \multirow[t]{2}{*}{$\mathbf{F}$} & R.H.D. & Nil & - & 3 & $33 \cdot 3$ & 3 & $35 \cdot 9$ & 11 & $40 \cdot 7$ & 14 & $46 \cdot 7$ & 2 & $48 \cdot 6$ \\
\hline & & & Recovered & Nil & - & 1 & $34 \cdot 3$ & Nil & - & 11 & $44 \cdot 0$ & 10 & $48 \cdot 3$ & 2 & $51 \cdot 1$ \\
\hline & \multirow[t]{6}{*}{ C } & \multirow[t]{3}{*}{$\mathbf{M}$} & R.H.D. & 2 & $30 \cdot 7$ & Nil & - & 2 & $34 \cdot 3$ & 8 & $40 \cdot 7$ & 8 & $42 \cdot 3$ & 5 & $48 \cdot 2$ \\
\hline & & & Recovered & Nil & - & 2 & $33 \cdot 4$ & 1 & $40 \cdot 0$ & 7 & $44 \cdot 7$ & 8 & $45 \cdot 6$ & 6 & $57 \cdot 1$ \\
\hline & & & Normals & 50 & $31 \cdot 6$ & 50 & $34 \cdot 7$ & 50 & $37 \cdot 7$ & 50 & $45 \cdot 1$ & 50 & $50 \cdot 2$ & 50 & $57 \cdot 2$ \\
\hline & & \multirow[t]{3}{*}{$\mathbf{F}$} & R.H.D. & Nil & - & 1 & $41 \cdot 4$ & 3 & $47 \cdot 3$ & 12 & $46 \cdot 1$ & 6 & $48 \cdot 8$ & 4 & $45 \cdot 7$ \\
\hline & & & Recovered & 1 & $52 \cdot 3$ & Nil & - & 1 & $30 \cdot 0$ & 7 & $41 \cdot 0$ & 9 & $44 \cdot 9$ & 4 & $49 \cdot 9$ \\
\hline & & & Normals & 50 & $31 \cdot 4$ & 50 & $35 \cdot 4$ & 50 & $40 \cdot 4$ & 50 & $43 \cdot 5$ & 50 & $50 \cdot 1$ & 50 & $52 \cdot 8$ \\
\hline \multirow[t]{14}{*}{ II* $^{*}$} & \multirow[t]{4}{*}{$\mathbf{A}$} & \multirow[t]{2}{*}{$\mathbf{M}$} & R.H.D. & 2 & $33 \cdot 2$ & 3 & $34 \cdot 4$ & 1 & $40 \cdot 9$ & 24 & $38 \cdot 4$ & 16 & $43 \cdot 1$ & 3 & $45 \cdot 9$ \\
\hline & & & Recovered & Nil & - & Nil & - & 4 & $36 \cdot 6$ & 9 & $41 \cdot 0$ & 3 & $41 \cdot 8$ & 2 & $43 \cdot 4$ \\
\hline & & \multirow[t]{2}{*}{$\mathbf{F}$} & R.H.D. & 4 & $28 \cdot 1$ & 2 & $36 \cdot 1$ & 10 & $35 \cdot 7$ & 30 & $43 \cdot 2$ & 18 & $44 \cdot 4$ & 7 & $48 \cdot 2$ \\
\hline & & & Recovered & 1 & $28 \cdot 6$ & 2 & $35 \cdot 2$ & 5 & $32 \cdot 8$ & 18 & $41 \cdot 1$ & 11 & $44 \cdot 4$ & 1 & $58 \cdot 2$ \\
\hline & \multirow[t]{4}{*}{ B } & $\mathbf{M}$ & R.H.D. & Nil & - & 3 & $37 \cdot 1$ & 2 & $41 \cdot 6$ & 14 & $39 \cdot 2$ & 18 & $47 \cdot 1$ & 3 & $49 \cdot 2$ \\
\hline & & & Recovered & 2 & $32 \cdot 7$ & 2 & $33 \cdot 4$ & 4 & $32 \cdot 8$ & 14 & $40 \cdot 6$ & 8 & $48 \cdot 9$ & 3 & $49 \cdot 1$ \\
\hline & & $\mathbf{F}$ & R.H.D. & 3 & $36 \cdot 5$ & 7 & $33 \cdot 6$ & 6 & $38 \cdot 7$ & 24 & $43 \cdot 2$ & 24 & $45 \cdot 9$ & 4 & $51 \cdot 4$ \\
\hline & & & Recovered & 1 & $33 \cdot 2$ & 2 & $31 \cdot 7$ & Nil & - & 16 & $44 \cdot 9$ & 19 & $50 \cdot 3$ & 3 & $51 \cdot 1$ \\
\hline & C & $\mathbf{M}$ & R.H.D. & 2 & $30 \cdot 7$ & 2 & $30 \cdot 2$ & 6 & $37 \cdot 0$ & 10 & $43 \cdot 7$ & 15 & $45 \cdot 0$ & 6 & $49 \cdot 4$ \\
\hline & & & Recovered & 1 & $43 \cdot 2$ & 3 & $31 \cdot 5$ & 1 & $40 \cdot 0$ & 10 & $46 \cdot 4$ & 13 & $46 \cdot 7$ & 7 & $55 \cdot 0$ \\
\hline & & & Normals & 50 & $31 \cdot 6$ & 50 & $34 \cdot 7$ & 50 & $37 \cdot 7$ & 50 & $45 \cdot 1$ & 50 & $50 \cdot 2$ & 50 & $57 \cdot 2$ \\
\hline & & $\mathbf{F}$ & R.H.D. & 2 & $28 \cdot 2$ & 5 & $37 \cdot 7$ & 4 & $46 \cdot 6$ & 14 & $45 \cdot 9$ & 13 & $45 \cdot 6$ & 5 & $46 \cdot 1$ \\
\hline & & & Recovered & 3 & $37 \cdot 3$ & 1 & $48 \cdot 2$ & 3 & $36 \cdot 6$ & 13 & $43 \cdot 1$ & 20 & $48 \cdot 9$ & 6 & $47 \cdot 1$ \\
\hline & & & Normals & 50 & $31 \cdot 4$ & 50 & $35 \cdot 4$ & 50 & $40 \cdot 4$ & 50 & $43 \cdot 5$ & 50 & $50 \cdot 1$ & 50 & $52 \cdot 8$ \\
\hline
\end{tabular}

* Series I consists of cases that have had rheumatic infection at least five years before, with no recurrence during the year prior to the last weighing. Series II consists of cases that have had theumatic infection at least two years before the last weighing, with no recurrence of infection during this two-year period. 
TARLE 2

THE EFFECT OF RHEUMATIC HEART DISEASE ON NUTRITION

\begin{tabular}{|c|c|c|c|c|c|c|}
\hline Series & Group & $\begin{array}{l}\text { Sex and age in } \\
\text { years }\end{array}$ & Type of control & $\begin{array}{l}\text { No. of cases with } \\
\text { R.H.D. }\end{array}$ & No. of controls & $\begin{array}{l}\text { Significant } \\
\text { difference }\end{array}$ \\
\hline I & $\begin{array}{c}\mathbf{A} \\
\mathbf{B} \\
\mathbf{C} \\
\mathbf{A B C}\end{array}$ & $\begin{array}{l}\text { M } 12-15 \\
\text { M } 11-15 \\
\text { M } 10,12-15 \\
\text { F } 11-15 \\
\text { M } 11-15 \\
\text { F } 11-15\end{array}$ & $\begin{array}{l}\text { Recovered } \\
\text { Recovered } \\
\text { Normal } \\
\text { Normal } \\
\text { Recovered } \\
\text { Recovered }\end{array}$ & $\begin{array}{l}29 \\
25 \\
25 \\
26 \\
77 \\
92\end{array}$ & $\begin{array}{r}9 \\
16 \\
250 \\
250 \\
47 \\
63\end{array}$ & $\begin{array}{l}\text { Nil } \\
\text { Nil } \\
\text { Nil } \\
\text { Nil } \\
5 \% \\
\text { Nil }\end{array}$ \\
\hline II & $\begin{array}{c}\text { A } \\
\text { B } \\
\mathbf{C} \\
\text { ABC }\end{array}$ & $\begin{array}{l}\text { M } 12-15 \\
\text { F } 10-15 \\
\text { M } 11-15 \\
\text { F } 10,11,13-15 \\
\text { M } 10-15 \\
\text { F } 10-15 \\
\text { M } 10-15 \\
\text { F } 10-15\end{array}$ & $\begin{array}{l}\text { Recovered } \\
\text { Recovered } \\
\text { Recovered } \\
\text { Recovered } \\
\text { Normal } \\
\text { Normal } \\
\text { Recovered } \\
\text { Recovered }\end{array}$ & $\begin{array}{r}44 \\
71 \\
40 \\
62 \\
41 \\
43 \\
125 \\
176\end{array}$ & $\begin{array}{r}18 \\
38 \\
31 \\
41 \\
300 \\
300 \\
84 \\
125\end{array}$ & $\begin{array}{l}\text { Nil } \\
\text { Nil } \\
5 \% \\
5 \% \\
\text { Nil } \\
\text { Nil } \\
\text { Nil } \\
\text { Nil }\end{array}$ \\
\hline
\end{tabular}

57 per cent. of relapses occurred within four years of a first attack, and Kaiser (1934) found that after five years only 25 per cent. of children had recurrences. In view of these findings only those cases were considered at first who had rheumatic infection at least five years previously. There may or may not have been further attacks during the five-year period, but no case was included that had suffered from a recurrence during the twelve months prior to the last weighing. This collection of cases is referred to in future as Series $I$, and consists both of children with rheumatic heart disease and of recovered cases.

As the numbers in Series I were not very large a second selection to be called Series II was made. This consisted of children who have had rheumatic infection at least two years previously and no recurrence of infection during the two-year period.

All groups in this paper have been compared by an analysis of variance, and less than 5 per cent. probability that the difference could be due to chance has been considered significant.

To test the validity of the recovered cases as controls, those children in Group C, Series I, were compared with normal controls for each sex separately. No significant difference was present.

\section{The Effect of Long-Continaed Heart Disease on Weight}

In the combined Groups A, B, and C of Series I, 77 boys with rheumatic heart disease were compared with 47 recovered cases. All the patients were between the ages of 11 and 15 years, and it was found that the patients with heart disease were significantly lighter (table 2 ). Similarly ninety-two girls were compared with sixty-three girl controls but no significant difference was detected. Each group, save for girls in Groups B and C, was then anatysed separately, and all the results showed no significant difference. Girls of Groups B and C were not compared with controls, because any difference could not be important as the combined female groups were not significantly different from the recovered controls.

Series II was treated similarly. In Group B both sexes were lighter than comparable recovered controls. Other groups showed no significant difference. When Groups $\mathrm{A}, \mathrm{B}$, and $\mathrm{C}$ were treated as a whole there was no significant difference.

\section{The Effect of Various Types of Rheumatic Disease on Growth}

Jones and Bland (1935) found the prognosis as regards the heart better in chorea than rheumatic fever. Ash (1941) found that in a ten-year period after rheumatic fever 30 per cent. of children had died as compared with 16 per cent. of deaths following chorea. It seemed worth while comparing cases who had had rheumatic fever only with controls. Children in Series I only were used, as the length of follow-up would be inadequate in Series II. The numbers in Group $C$ alone were large enough to permit analysis. No significant difference was found between such cases and normal controls (table 3).

Children with rheumatic heart disease and no previous history of rheumatic infection cannot have received the long bed rest and care which is advisable if permanent heart damage is to be avoided or minimized. It was thought that this lack of nursing might have an effect on growth. In Series I all such cases were compared with controls (table 3). The only significant difference was among Group C boys where such a difference could be found by chance in less than 1 per cent. of such groups of observations.

In Series II only members of Group B were considered because in table 2 this group alone had been significantly lighter than the controls. The results of comparison with controls of cases having 
TABLE 3

THE EFFECT ON GROWTH OF RHEUMATIC FEVER ONLY, AND OF NO HISTORY OF ANY FORM OF RHEUMATIC INFECTION IN SERIES I

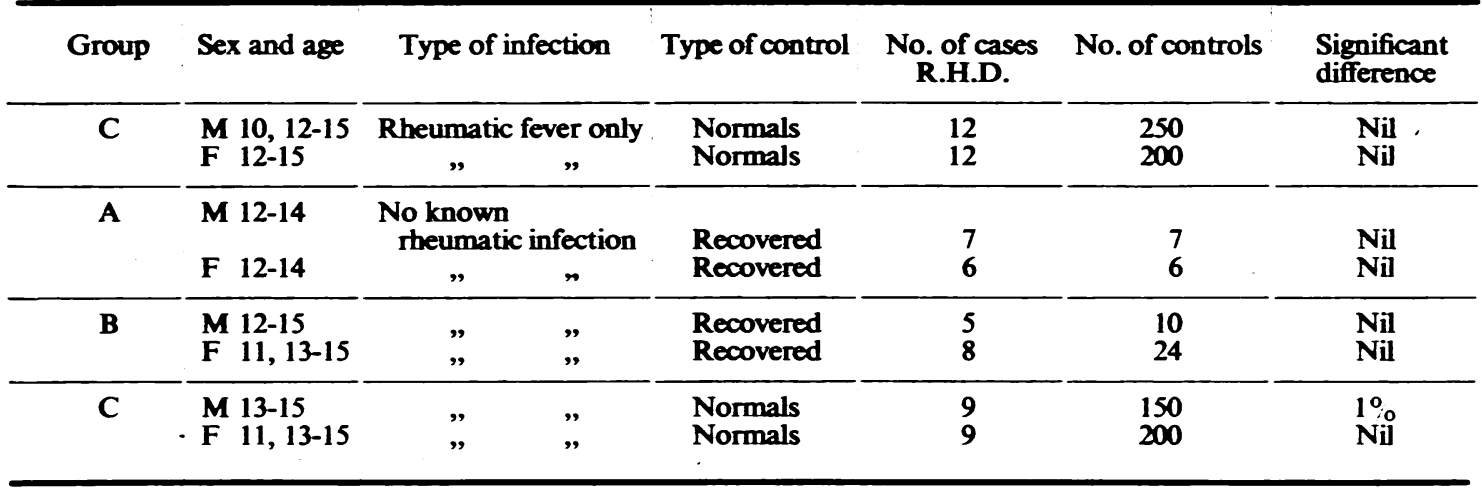

had more than one attack of rheumatic infection (rheumatic fever, chorea, or both), scarlet fever only, chorea only, rheumatic fever only, or with no history of these diseases, showed no significant difference (table 4). Group B boys with a history of rheumatic fever only were not analysed as they were all heavier than the control series. The meaning of these results is doubtful because the numbers considered were small.

\section{The Effect of Large Hearts on Nutrition}

Only cases in Series I were considered, so that a time interval of at least five years would permit cardiac disease to affect the growth of these children. Enlargement was judged clinically, and no radiographic measurements were available for confirmation, but only undoubted cases were included. All cases showed evidence of affection of the mitral, aortic, or both valves. Because the numbers were small, all groups were taken together, the sexes being considered separately. Twenty-two boys compared with forty-nine recovered controls showed no significant difference.
In the female group, where twenty-four cases were compared with sixty-one recovered controls a difference significant to 5 per cent. was found, the rheumatic children being lighter.

\section{Discussion}

Although the number of cases analysed is quite large, only Group B in Series I were lighter than the controls. In Series II in no single group were weights significantly less than in the controls, but with all the males combined the weights were significantly lower. The significance in each case was 5 per cent., which is usually considered statistically significant in biological investigations. However, when a large number of analyses are carried out such differences would be expected 1 in 20 times even if no difference existed. The results, therefore, could be due to chance. If there is any difference, then it is small and of no practical importance.

Children with a history of rheumatic fever are very little if at all lighter than normal children. The

TABLE 4

THE EFFECT OF VARIOUS FORMS OF RHEUMATIC INFECTION ON GROWTH IN SERIES II, GROUP B

\begin{tabular}{|c|c|c|c|c|c|}
\hline Sex and age & Type of infection & Type of control & $\begin{array}{l}\text { No. of cases with } \\
\text { R.H.D. }\end{array}$ & No. of controls & $\begin{array}{l}\text { Significant } \\
\text { difference }\end{array}$ \\
\hline $\begin{array}{l}\text { M } 13,14 \\
\text { F } 11-14 \\
\text { F } 10,11,13,14 \\
\text { M } 13-15 \\
\text { F } 13-15 \\
\text { F } 10,11,13-15 \\
\text { M } 11-15\end{array}$ & $\begin{array}{l}\text { Multiple* } \\
\text { Multiple* } \\
\text { Scarlet fever } \\
\text { Chorea } \\
\text { Chorea } \\
\text { Rheumatic fever } \\
\text { No rheumatic fever, } \\
\text { chorea, or scarlet }\end{array}$ & $\begin{array}{l}\text { Recovered } \\
\text { Recovered } \\
\text { Recovered } \\
\text { Recovered } \\
\text { Recovered } \\
\text { Recovered }\end{array}$ & $\begin{array}{r}6 \\
8 \\
9 \\
7 \\
6 \\
30\end{array}$ & $\begin{array}{l}22 \\
37 \\
38 \\
25 \\
38 \\
41\end{array}$ & $\begin{array}{l}\text { Nil } \\
\text { Nil } \\
\text { Nil } \\
\text { Nil } \\
\text { Nil } \\
\text { Nil }\end{array}$ \\
\hline F $10,11,13-15$ & fever & $\begin{array}{l}\text { Recoovered } \\
\text { Recovered }\end{array}$ & $\begin{array}{l}13 \\
14\end{array}$ & $\begin{array}{l}33 \\
41\end{array}$ & $\begin{array}{l}\text { Nil } \\
\text { Nil }\end{array}$ \\
\hline
\end{tabular}

* Multiple infection = at least two attacks of rheumatic fever, or chorea, or both. 
absence of any history of rheumatic infection was significant in Group $C$ boys only. This could be due to chance, and the suggestion is supported because although children of both sexes in Group B Series II were under weight, the type of infection showed no evidence of affecting growth.

\section{Conchasions}

Rheumatic heart disease probably has no inhibiting effect on the growth of children once the infection has subsided. The type of rheumatic infection and the presence of cardiac enlargement are also without effect.

I wish to acknowledge my indebtedness to Professor C. Bruce Perry for his advice, encouragement, and help. Professor R. H. Parry supplied me with my normal controls, and I am very grateful to Mr. H. Todd for advice on statistics.

\section{Reperences}

Ash, R. (1941). Amer. Heart J., 22, 439.

Campbell, M., and Warner, E. C. (1930). Lancet, 1,61 .

Glover, J. A. (1934). Proc. roy. Soc. Med., 27, 953.

Gray Hill, N. (1933). L.C.C. Annual Report, Vol. 4, Part 3. London.

Jones, T. D., and Bland, E. F. (1935). J. Amer. med. Ass., 105, 571.

Kaiser, A. D. (1934). Ibid., 103, 886.

Mackie, T. T. (1926). Amer. J. med. Sci., $172,199$.

Medical Research Council Report (No. 114) (1927). London.

Miller, R. (1928). Lancet, 1, 1005.

Ministry of Health Report No. 44. (1927.) London.

Swift, H. F., in Nelson, Loose Leaf Medicine, 1, 424. New York.

Vining, C. W. (1928). Med. J. Rec., 128, 395.

Wilson, M. G., Lingg, C., and Croxford, G. (1928). Amer. Heart J., 4, 164. 